\title{
PEMBERDAYAAN MASYARAKAT MELALUI POTENSI EKOWISATA DI KECAMATAN MENTARANG DAN MALINAU BARAT KABUPATEN MALINAU
}

\section{Community Empowerment Through The Potential Of Ecotourism In The Malinau Regency West And Mentarang National Park Malinau}

\author{
Witri Yuliawati $^{1}$, Endik Deni Nugroho ${ }^{2}$ \\ ${ }^{1}$ Jurusan Ekonomi Pembangunan, Fakultas Fakultas Ekonomi, Universitas Borneo Tarakan, \\ ${ }^{2}$ Jurusan Pendidikan Biologi, Fakultas Keguruan dan Ilmu Penddidikan, Universitas Borneo Tarakan,, Jl. Amal \\ Lama No.1 Kota Tarakan \\ *e-mail: Witriyuliawati75@gmail.com
}

\begin{abstract}
ABSTRAK
Kabupaten Malinau merupakan salah satu Kabupaten di Provinsi Kalimantan Utara yang memiliki potensi sumberdaya alam hutan yang luas sehingga Kabupaten Malinau ditetapkan sebagai Kabupaten Konservasi di Kalimantan Utara. Penetapan Malinau sebagai kabupaten konservasi merupakan salah satu konsep yang diharapkan dapat mengatasi permasalahan lingkungan, namun tidak memberikan dampak ekonomi dan kesejahteraan masyarakat secara langsung. Tujuan dari kegiatan pengabdian ini adalah memberikan dan meningkatkan wawasan serta kesadaran masyarakat akan potensi-potensi daerah yang akan meningkatkan kesejahteraan, Kegiatan pengabdian ini dilakukan dengan metode pendidikan masyarakat dan pelatihan menunjukkan bahwa masyarakat belum terlalu Memberikan perhatian kepada potensi ekowisata yang ada dan hal tersebut membutuhkan dukungan dari berbagai pihak terutama pemerintah.
\end{abstract}

Kata Kunci : ekowisata, potensi, sumberdaya alam, Malinau

\begin{abstract}
Malinau Regency is one of regencies in the province of North Borneo that has the potential of natural resources of a vast forest so the county Conservation District designated as Malinau in North Borneo. Determination of the Malinau Regency, as conservation is one of the concepts that are expected to address the environmental problems, but did not give the economic impact and the welfare of society directly. The purpose of this service is to provide activities and increase insight and awareness of potential-potential areas that will improve the welfare of this devotion, the activities carried out by the method of community education and the training shows that the public is not yet too Gives attention to the potential for ecotourism and it needs support from various parties especially Government.
\end{abstract}

Keyword : ecotourism, potential, natural resources, Malinau

\section{(1) PENDAHULUAN}

Kabupaten Malinau merupakan Kabupaten terluas di Provinsi Kalimantan Utara yaitu dengan luas 4.2 juta $\mathrm{Ha}$ dan berbatasan langsung dengan Negara bagian Serawak Malaysia. Kabupaten Malinau merupakan kawasan perhuluan sungaisungai besar di wilayah propinsi Kalimantan Utara. Luas kawasan hutan di wilayah ini mencapai 3,9 juta Ha (90\%), dimana hampir $50 \%$ dari kawasan hutan adalah kawasan Taman Nasional Kayan 
Mentarang dan hutan lindung. Oleh karena potensi tersebut, maka Kabupaten Malinau ditetapkan sebagai Kabupaten Konservasi di Kalimantan Utara. Masyarakat di Kabupaten Malinau belum merasakan dampak ekonomi dari ditetapkannya Malinau sebagai Kabupaten Konservasi, dari hasil identifikasi Pusat Pengabdian Kepada Masyarakat Universitas Borneo Tarakan, menunjukkan bahwa kabupaten konservasi merupakan salah satu konsep yang diharapkan dapat mengatasi permasalahan lingkungan, namun tidak memberikan dampak ekonomi dan kesejahteraan masyarakat secara langsung.

Berdasarkan uraian di atas, maka perlu adanya kesadaran dari masyarakat Malinau untuk dapat memanfaatkan potensi daerahnya sehingga dapat meningkatkan kesejahteraan mereka. Untuk menjawab permasalahan kurangnya kesadaran masyarakat Malinau khususnya Kecamatan Malinau Barat dan Kecamatan Mentarang maka dengan melalui program KKN PPM melakukan kegiatan berupa penyuluhan pentingnya peranan masyarakat dalam memanfaatkan potensi wisata, melakukan pembentukan, pembinaan dan pengembangan kelompok usaha Ekowisata, dan penyuluhan dan pelatihan pengelola usaha ekowisata;

Target dari KKN PPM ini adalah adanya peningkatan partisipasi masyarakat dalam pengelolaa ekowisata, peningkatan swadana dan swadaya masyarakat dan pemerintah desa dalam pengelolaan ekowisata. Luaran dari kegiatan pengabdian ini adalah (1) publikasi ilmiah pada jurnal ilmiah (2) publikasi pada media cetak/elektronik (3) Peningkatan pendapatan dan partisipasi masyarakat (4) Terlaksananya Bimbingan Teknis/Pendampingan pembinaan dan Pengembangan pengembangan produk ekowisata.

Sejak tahun 2002 Indonesia telah mencanangkan Tahun Ekowisata, dan telah dirumuskan prinsip dasar pengembangan ekowisata di Indonesia yakni: Pelestarian ; (2) Pendidikan;
Pariwisata; (4) Perekonomian; dan (5) Partisipasi masyarakat setempat. Ekowista didefiniskan oleh berbagai pakar, diantaranya Hetzer (1965) sebagaimana disitir Fennel (1999) dan Blamey (2001), telah menggunakan istilah yang mirip ketika ia memperkenalkan empat prinsip wisata bertanggung jawab (responsible tourism), yaitu meminimalkan dampak lingkungan, menghormati budaya setempat, memaksimalkan manfaat bagi masyarakat lokal, dan memaksimalkan kepuasan wisatawan (Suardana, 2006).

\section{(2) METODE}

Metode yang digunakan untuk menjawab permasalahan atau untuk mencapai tujuan kegiatan program pengabdian KKN PPM ini adalah dengan metode pendidikan masyarakat dan pelatihan. Pendidikan masyarakat dilakukan dengan teknik presentasi dan ceramah di empat desa yang berada di Kecamatan Malinau Barat dan Kecamatan Mentarang Kabupaten Malinau. Volume pekerjaan dalam bentuk Jam Kerja Efektif Mahasiswa (JKEM), dengan jumlah mahasiswa sebanyak 72 orang, dan waktu pelaksanaan di lapangan selama 40 hari, tidak termasuk pembekalan, persiapan, evaluasi atau desiminasi kegiatan.

\section{(3) HASIL DAN PEMBAHASAN}

Tempat pelaksanaan kegiatan $\mathrm{KKN}$ PPM dilaksanakan di 6 Desa, yakni Desa Long Bila, Desa Sentaban, Desa Long Kenipe, Desa Long Gafid, Desa Long Bisai dan Desa Pulau Sapi. Adapun kegiatan-kegiatan yang dilaksanakan dalam KKN-PPM ini adalah :

\section{a. Penyuluhan Ekowisata}

Program Ekowisata ini dilaksanakan bertujuan untuk memberikan pengetahuan tentang peranan pariwisata terhadap perekonomian dan memberikan pemahaman dalam memanfaatkan potensi ekowisata yang ada di Desa Long Bila, Sentaban, Long Bisai dan Long Gafid serta Pulau Sapi. 


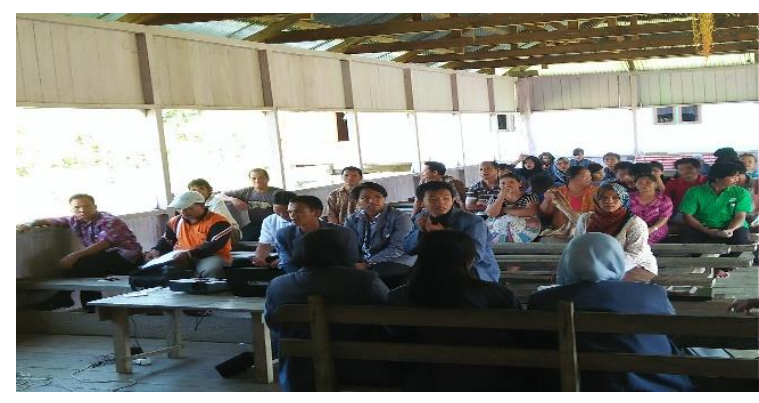

Gambar 1. Kegiatan Penyuluhan Ekowisata

\section{b. Penyuluhan Kelompok Usaha}

Ekowisata

Program pembentukan Kelompok usaha ekowisata bertujuan untuk memberikan semangat kepada masyarakat untuk lebih maju secara ekonomi dan social melalui usaha bersama terutama dalam mendukung ekowisata

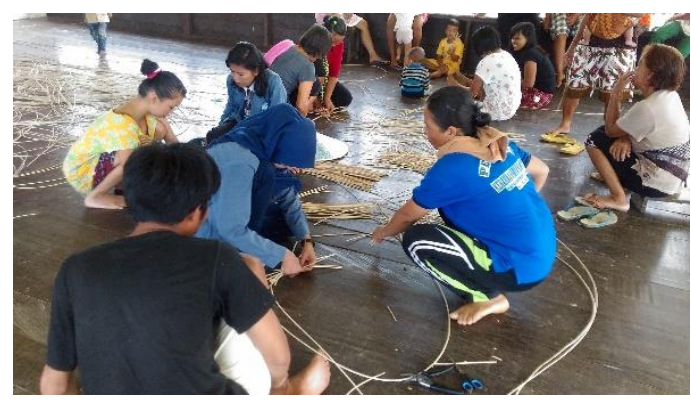

Gambar 2. Usaha Ekowisata

\section{c. Pembuatan Sarana Fisik Ekowista}

Pembuatan sarana fisik seperti penunjuk arah, penunjuk jalan, dan gapura, dilakukan dengan maksud memberikan tanda atau informasi kepada masyarakat dan pengunjung yang datang mengenai lokasi wisata.

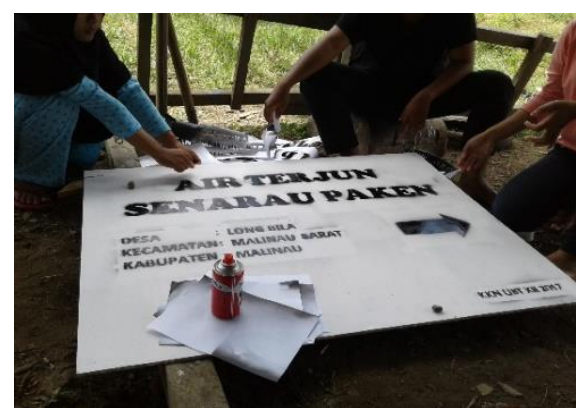

Gambar 3. Pembuatan Sarana Fisik d. Pelatihan Pembuatan Sarana Promosi Pelatihan ini bertujuan untuk memberikan wawasan akan pentingnya sarana promosi guna memperkenalkan dan memperlihatkan potensi wisata daerah.

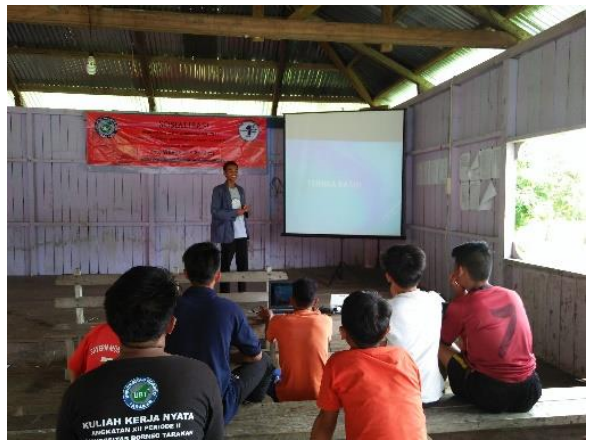

Gambar 4. Pelatihan Pembuatan Sarana Promosi

\section{e. Pelatihan Pemandu Wisata}

Pelatihan pemandu wisata bertujuan untuk memberikan wawasan kepada masyarakat untuk menjadi pemandu wisata yang baik bagi pengunjung yang datang.

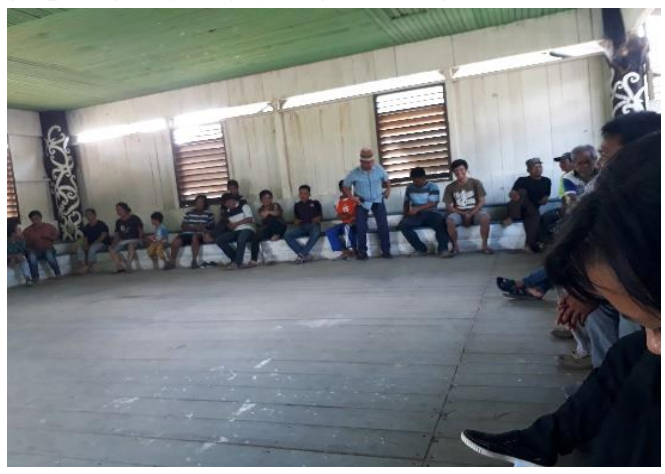

Gambar 5. Pelatihan Pemandu Wisata

Seluruh kegiatan yang direncanakan dalam program KKN PPM ini dapat terlaksana dengan baik. Kegiatan ini dilaksanakan di empat desa saja, hal ini dikarenakan jarak desa yang saling berdekatan dan tidak memiliki potensi wisata. Kendala yang dihadapi selama pelaksanaan pengabdian ini adalah masih rendahnya partisipasi masyarakat desa dalam mengikuti setiap kegiatan yang dilaksanakan. Hal ini dikarenakan kurangnya jumlah masyarakat terutama pemuda yang sebetulnya menjadi target sasaran dalam pengabdian KKN PPM dan 
juga dikarenakan masyarakat desa sebagaian besar berprofesi sebagai petani sehingga sukar untuk menyediakan waktunya untuk mengikuti setiap kegiatan.

\section{(4) PENUTUP}

Kegiatan pengabdian KKN PPM telah memberikan beberapa pembelajaran bagi masyarakat dan mahasiswa tentang pemanfaatan potensi desa baik dari alam maupun memanfaatkan limbah untuk dijadikan kerajinan tangan dan manfaat dari adanya kelompok usaha desa, yang dapat dijadikan sumber pemasukan yang akan meningkatkan kesejahteraan masyarakat. Tujuan dari Kabupaten Malinau sebagai Kabupaten Konservasi dapat tercapai jika seluruh pihak baik dari akademisi, pemerintah dan masyarakat dapat bekerja sama dengan baik. Diharapkan kepada pemerintah untuk selalu mendukung kegiatan masyarakat baik dari mengadakan sosialisasi pentingnya pemanfaatan potensi desa, pelatihan-pelatihan berupa pengolahan limbah, bahan makanan, souvenir , sehingga produk yang dihasilkan bisa menjadi produk khas wisata di Kabupaten Malinau. Pemerintah diharapkan menyediakan fasilitas di lokasi objek wisata, seperti sarana transportasi, jalan, penerangan dan sarana prasarana lain yang dapat meningkatkan minat wisatawan untuk berkunjung ke lokasi wisata yang ada di Kabupaten Malinau khususnya Kecamatan Malinau Barat dan Kecamatan Mentarang.

\section{(5) UCAPAN TERIMAKASIH}

Terimakasih disampaikan kepada :

(1) KEMENRISTEK DIKTI yang telah mendanai pengabdian kepada masyarakat melalui kegiatan KKN PPM (2) LPPM UBT yang telah membantu dalam pelaksanaan kegiatan pengabdian KKN PPM (3) Camat, Kepala Desa dan Masyarakat di Kecamatan Malinau Barat dan Kecamatan Mentarang (4) Mahasiswa
KKN di Kabupaten Malinau (5) Semua pihak yang telah membantu dan mendukung kegiatan Pengabdian ini.

\section{(6) DAFTAR RUJUKAN}

[BPS] Badan Pusat Statistik Kalimantan Timur. 2013. Kalimantan Timur dalam Angka Tahun 2013.

Ishak. AF. 2009. Strategi Pengembangan Kawasan Perbatasan Kalimantan Timur. Pemerintah Provinsi Kalimantan Timur.

Jumiati E, Titik I, Willem. 2010. IbM Pengolahan Kelapa Terpadu di Kecamatan Sebatik. Fakultas Pertanian: Universitas Borneo Tarakan

Margiyono dan Syaiful Anwar. 2012. Black Market di Perbatasan Indonesia- Malaysia (Studi Kasus Perdagangan Ilegal di Tarakan dan Kabupaten Malinau

Peraturan Pemerintah No. 26 Tahun 2008. Tentang Tata Ruang Wilayah Nasional

[Pemrov Kaltara) Pemerintah Provinsi Kalimantan Utara. Kondisi Wilayah. http://kaltaraprov.go.id

[PPM] Pusat Pengabdian Kepada Masyarakat. 2013. Evaluasi Pelaksanaan KKN Universitas Borneo Tarakan Tahun 2013. UBT: Tarakan

[PPM] Pusat Pengabdian Kepada Masyarakat. 2010. Laporan KKN UBT 2010 di Kecamatan Krayan.

[PPM] Pusat Pengabdian Kepada Masyarakat. 2012. Laporan KKN UBT di Kecamatan Sebatik.

Undang-Undang No. 26 Tahun 2007. Tentang Penataan Ruang dan Aplikasinya.

Undang Undang No. 43 Tahun 2008. Tentang Wilayah Negara

Witri Y, Endik D.N. PEMBERDAYAAN MASYARAKAT MELALUI ... 